\title{
Redeveloping history in postsocialist Poland
}

\author{
Jaro Stacul
}

\begin{abstract}
This article analyzes the reorganization of public memory space in postsocialist Poland and how the state and municipal councils use it to legitimate themselves. Drawing on research conducted in Gdansk, the birthplace of the social movement (Solidarność) that questioned the legitimacy of the socialist state in the 1980s, it examines the proposed redevelopment of the shipyard where the movement was formed. While the redevelopment sets out to create a public memory space, it is rife with contradictions, for it involves demolishing many buildings associated with the movement. What legitimated the municipal council's authority over its memorial landscapes was not so much its rediscovery of complex local histories as it was its ability to define the local past in "material" terms.
\end{abstract}

Keywords: heritage, history, memory, Poland, postsocialism, redevelopment, shipyard

On 25 October 2015, Law and Justice (Prawo i Sprawiedliwość), a political force championing nationalist and Christian values, won the parliamentary elections in Poland by a large majority. It ran a platform built on conservative Roman Catholicism, resistance to Europe, and opposition to immigration. It defeated Civic Platform (Platforma Obywatelska), a party with a vision of Poland as an integral part of a European Union (EU) dedicated to market and pluralist principles, which had governed the country since 2007 and had overseen Poland's transformation into the "tiger economy" of Central and Eastern Europe (Hardy 2009). This article examines the symbolic order propagated by Civic Platform when it was in office and the contradictions with which it was rife.
If the postsocialist change involved the redefinition of virtually everything, as Katherine Verdery (1999: 35) has suggested, what made this change particularly problematic was the fact that morality, social relations, and basic meanings were not redefined once and for all: rather, their redefinition remains on the agenda of political forces competing for power. At a time when international aid agencies and political advisors encourage postsocialist and other governments to redefine the role of the state as a "consumer state" as opposed to a "citizen state," national governments must reconcile two tasks: on the one hand, they have to follow the directives of international and supranational agencies; on the other hand, they have to legitimate themselves and reorder people's meaningful worlds. 
An essential component of self-legitimation is the production of places of memory that would help forge a shared local or national identity. In the context of this process, the creation of spectacular urban spaces may induce feelings of hope, pride, and enthusiasm for the state in citizens (Laszczkowski 2011). Yet producing such places in Poland is a complicated task, for post-1945 Poland bears little resemblance to the country that appeared on maps before the end of World War II. Because of subjection to partitioning powers, from the late eighteenth century until the early twentieth century the idea of "Poland" was associated with a nation, a "culture," and Roman Catholicism, but not with a state or a clearly bounded territory (Davies 2001; Lukowski and Zawadzki 2006; Mach 2007; Porter-Szücs 2014; Zubrzycki 2006). The idea of Poland as a homogeneous nation made up of Polish-speaking Catholics became powerful after World War II, particularly after the expulsion of non-Polish elements and the removal of the legacies of ethnic minorities from national history (Mach 2007: 63-65).

Before Law and Justice imposed its own nationalistic interpretation of history, many Polish regions and towns set out to rediscover their multicultural heritages and redefine their identities as different from other regions and from the homogeneous national identity formerly advocated by the political establishment. Behind this interest in regional and local identities were the EU's pressures on member states to create regional structures dealing with the disbursement of regional funds and, more importantly, to devolve power to regions in order to counter the power of the nation-state. As a result, municipal councils had more authority on their memorial landscapes (Ochman 2009: 393-400; Parkin 2013) than was previously the case. What characterized this "rediscovery" was also the fact that after 1989 both the myth of Poland as a homogeneous nation and that of its intrinsic Catholicity became open to contestation (OrlaBukowska 2006; Zubrzycki 2011: 38-45). Yet promoting regional cultures and revisiting national history in a country where regional iden- tity is segmented with national identity can have unintended consequences, given that cultural unity looms large in popular discourses (Parkin 2013: 119).

This article discusses the multilayered processes of the reorganization of public memory space in the city of Gdańsk on the Baltic Sea and particularly Civic Platform's influence on such processes. The city's history is characterized by the complex interplay of different legacies left by the people who lived there and by the powers that ruled over the area. Gdańsk was founded in the early tenth century as a town of the Slavic dukes of Pomerania. Between the early fourteenth century and the middle of the fifteenth century, it was under the control of the Order of the Teutonic Knights, and its population was predominantly German. Although Gdańsk was incorporated into the Kingdom of Poland in 1466, it was not completely subordinated to the Polish crown. Gdańsk's economic prosperity was based on its monopoly on Polish corn, wood, and the export of pitch to Western Europe, and it reached its apogee in the sixteenth and seventeenth centuries. In this period, most of its inhabitants were ethnic Germans, and other ethnic groups were never present in significant numbers. Between the Second Partition of Poland (1793) and the end of World War I, Gdańsk was part of the Prussian state. After World War I, Poland pushed for the incorporation of the city into the new Polish state. However, the League of Nations assigned it to neither Germany nor Poland, creating instead the Free Town of Danzig in 1920. Control over the city remained a source of conflict until the German attack on the Polish military post in Gdańsk in 1939 that started World War II (Tighe 1990: 143-153).

At the end of the war, Gdańsk became part of Poland, but most of its Polish inhabitants were new to the area, having just come from territories lost to the Soviet Union to replace the German expellees (Lukowski and Zawadzki 2006: 279; Tighe 1990: 224-225). Gdańsk, in turn, was reinvented as a Polish and socialist city and reconstructed solely in terms of its Polish heri- 
tage (Czepczyński 2004: 279; Friedrich 2012: 121-123). In 1980, it saw the formation of Solidarność (Solidarity), the mass social movement guided by the principle of labor self-government that contributed to the downfall of the socialist state. ${ }^{1}$ The city underwent significant social and economic transformations after the demise of socialism, most notably after Poland's adoption of a market economy and its subsequent accession to the EU in 2004. Gdańsk is now shifting from an industrial to a services-dominated economy and is redefining itself through culture in order to attract tourists, investors, and potential residents. Yet given Gdańsk's complicated history, its "local culture" and "heritage" are difficult to define. What makes this definition particularly challenging is the fact that both are entangled with larger projects of power and claims to history. How do municipal councils use the reorganization of public memory space to legitimate themselves, in practice, in times of rapid change?

\section{City of "freedom"}

In an attempt to answer this question, I will analyze the transformation of postindustrial areas into public memory spaces in the city of Gdańsk from 2008, when the city experienced unprecedented economic growth. ${ }^{2}$ During this period, the inhabitants of Gdańsk witnessed the growth of the volume of construction across the city and became exposed to a rhetoric that cast Gdańsk itself and Poland as territorial units in the process of physical transformation. This rhetoric was expressed particularly by the slogan "We are building Poland" (Budujemy Polskę), which was deployed by the Polish state in 2010 in connection with the promotion of large-scale projects funded by the EU, such as the construction of roads and the improvement of infrastructure, in preparation for the European football championships that would be played in Poland and the Ukraine in 2012. ${ }^{3}$ The mayor of Gdańsk, affiliated with Civic Platform, contributed to the spread of the slogan by presenting himself as the person promoting large-scale construction works in the city and by establishing a relationship of historical continuity between himself and Mayor Leopold von Winter, who, between 1863 and 1875, commissioned the construction of sewage and water supply systems as well as of the tramline network. ${ }^{4}$ The remark "But at least something is being built" (Ale przynajmniej sie buduje), often made by locals in response to other people's dismay at such unprecedented levels of construction, is very telling about the meanings attached to construction itself as a conventional metaphor for positive change. ${ }^{5}$ However, it also resonates with the ideology of "transition" embraced by most governments across the former socialist world (Laszczkowski 2011: 80-82).

In the context of these developments, in 2010 the municipal council put forward the city's candidacy for the status of European Capital of Culture in 2016. ${ }^{6}$ Because Capital of Culture status gives European cities the financial benefits that go along with the designation, the competition in Poland generated intense rivalry between candidate cities (Grzeszak and Janicki 2011). Thus, the mayor promoted an image of Gdańsk as the ideal place for business and investment (Adamowicz 2008) and as a European city with a multicultural heritage where different histories intersect (Urząd Miejski w Gdańsku 2011: 3-5). While emphasis on multicultural heritage reflected the EU's attempts to engineer a European identity perceived as based on a common past, the inhabitants of Gdańsk also became confronted with a history of the city as a site of national resistance to the socialist state. This was endorsed by Law and Justice and propagated primarily (albeit not exclusively) by the Institute of National Remembrance (IPN) ${ }^{7}$ through a wide range of initiatives that cast the socialist era as a time of political repression.

Central to the city's cultural heritage defined by the Gdańsk 2016 organizing committee (Urząd Miejski w Gdańsku 2011: 15) was the notion of a "culture of freedom" (kultura wolności). While the notion was meant to "brand" the city, it is a reminder of Gdańsk's glorious past 
as a free port. However, as the application materials for the title of European Capital of Culture make it clear, this association is particularly a reference to the city being the birthplace of Solidarność. $^{8}$ The significance, in Polish history, of this workers' movement contrasts with the limited role that workers played in the antisocialist revolutions in other eastern European countries (Kideckel 2008: 30). Yet the "freedom" (wolność) that Solidarność championed was primarily the freedom of the individual historically advocated by the Roman Catholic Church. ${ }^{9}$ Obviously, the notion is more complex than suggested by this very brief analysis (Bauman 1988). Suffice it to say, for the purposes of this article, that while emphasis on freedom in the application materials is an implicit reference to Poland's struggle for freedom, it also serves to stress that Gdańsk has long been part of larger entities, such as Poland and the EU, which were founded on the principles of freedom, democracy, and respect for human rights.

One of the key points of the application materials is that thanks to the revolution led by Solidarność in the 1980s, the Poles who had settled in Gdańsk after World War II gained for the first time a sense of community (Urząd Miejski w Gdańsku 2011: 9). Yet 20 years after freedom had been restored, a sense of community and solidarity was lost. ${ }^{10}$ Culture, the application materials state, can play a crucial role in rebuilding solidarity. In being awarded the status of European Capital of Culture, Gdańsk would become not just a symbol of the struggle for freedom but also a symbol of the culture of freedom. The application materials stress that rebuilding solidarity is conditional on the revitalization of postindustrial areas for cultural purposes (Urząd Miejski w Gdańsku 2011: 10). In sum, "building," "solidarity," and "freedom" figured centrally in Civic Platform's rhetoric at the national and local levels. However, how to shape a "culture of freedom" with which most residents of Gdańsk could identify and how to turn postindustrial areas into public memory spaces in which solidarity could be rebuilt turned out to be challenging tasks for the Civic
Platform-led municipal council. These are issues to which I now turn.

\section{Place and placemaking in the "city of freedom"}

Postsocialist cities like Gdańsk resemble "kaleidoscopes," in the sense that by sharing fragments of different eras, they refract history and geography (Richardson 2008: 6). Between the sixteenth and the seventeenth centuries, Gdańsk was dominated by a class of predominantly German and Dutch merchants, and very little trace of the Polish language could be found there. Yet even in the late eighteenth century among the Polish speakers living in the region, "Poland" represented an abstract idea (Tighe 1990: 41-42). Moreover, the Dutch and the Germans dominated in art and architecture, as shown by the Dutch-style buildings and brick Gothic churches, reconstructed after World War II, that line the main streets of the historical center (Główne Miasto). However, because such buildings are now the domain of tourists and foreign investors, many residents can hardly afford the restaurants and upscale cafés in the area, and do not look upon it as their own. As a resident told me, "We never go to Główne Miasto. It is a place for tourists."

Gdańsk's physical and cultural landscape has been altered by the many rulers over the city, and the shapes of the urban scenery were often used for political reasons: the Nazis manipulated Gdańsk's historical legacy in an effort to demonstrate Germany's supremacy over that part of Europe (Tighe 1990: 154-177); likewise, the socialist state endeavored to remove the German elements from the city landscape. Although the municipal council has been promoting an image of Gdańsk as a place where different histories and historiographies intersect, the dramatic transformations that the city witnessed in the twentieth century conjure up images of Gdańsk as a city where different eras follow (rather than intersect) one another in a linear fashion, in the sense that one era seems to obliterate another. ${ }^{11}$ 
At a time when the Polish state was promoting large-scale projects under the slogan "We are building Poland," the reinvention of Gdańsk as a "city of freedom" became one of the priorities of the municipal council. However, this reinvention also involved the reorganization of public memory space and entailed dealing with the postindustrial areas associated with the city's socialist past and the history of Solidarność. An extensive area poised to be redeveloped was that of the Gdańsk Shipyard. The shipyard has a complex legacy as both a socialist factory and a site of dissent. Like other sites associated with the socialist era (Murawski 2011: 6-7; Pozniak 2015: 71-72), the shipyard's place in the national imagination has often been contested. Formerly a German shipyard, after 1945 it became the pride of the Polish state and was meant to be the material form of socialist ideology (Jarecki 1985: 24-25; Wojciechowski 1966). Ironically, in 1980 it became the cradle of Solidarność and the location where socialist ideology itself was contested.

In official discourses, Solidarność and the shipyard are associated in Polish history with a struggle for "freedom." Yet their histories are rife with paradoxes: when Solidarność was formed, it set out to protect workers' interests, and the 21-point Gdańsk agreements between Solidarność and the socialist state signed in 1980 included, inter alia, the right to strike and form an independent trade union. However, Solidarność changed its goals once it became a political party: after its landslide victory in the 1989 elections, it splintered into several political forces with a broad range of platforms. Some of these focused on the formation of market economic classes and turned against the workers they were expected to protect, ${ }^{12}$ many of whom would become the victims of such economic reforms (Dunn 2004: 8-18; Hardy 2009: 115-126; Ost 2005: 37-59; Shields 2007). Moreover, despite the widespread confidence that economic advancement would continue, the economic gap between the rich and the poor was getting wider (Galbraith 2014: 59-61). Because there is no consensus in the Polish memory field on the significance of Solidarność, attempts to commemorate it at the national level have frequently failed (Bernhard and Kubik 2014: 77; Mark 2010: 12), and even in Gdańsk it is attached to different meanings by different people (Latoszek 2003; Michałowski 2010).

The shipyard, in turn, was totally unprepared for the challenges posed by free markets and the rapid decline of heavy industry, and in 1996 it went bankrupt. Later on, it was bought by a Ukrainian investor. Nowadays, it is much smaller than it was in the socialist period, given that 70 hectares of land no longer devoted to shipbuilding had been sold to private investors. In official discourses, it is referred to as the cradle of a "national myth" (mit narodowy): its main gate (Gate 2) is a tourist attraction, so was the place where the Solidarność movement's historic leader (and then Polish president) Lech Wałęsa used to work as an employee of the shipyard.

However, past Gate 2, visitors face a scenario of desolation: several buildings are abandoned and earmarked for demolition, and huge open spaces are densely overgrown. Those who hold administrative positions in the shipyard refer to it as "typically socialist" on the grounds that it embodies a socialist legacy. In 2008, an employee of a public institution headquartered there drew my attention to this aspect by asking: "Don't you think that this place looks socialist?" Implicit in his view is the idea that since the relationships of sociality that gave it life have dissolved, the shipyard needs to be transformed, and epochs should neatly succeed one another in sequential, linear fashion (Gordillo 2014: 83). To paraphrase Ann Stoler (2008: 194), the shipyard's ruins condense different senses of Poland's postsocialist history. Thus, because of the different visions of the shipyard upheld by different actors, the shipyard became a contested object of planning.

\section{Demolishing and redeveloping history}

As Poland witnesses the privatization of its economy, postindustrial sites such as the Gdańsk 
Shipyard face a dilemma, namely, how to regulate construction and renovations in order to be economically viable and how to have them become public memory spaces (Kosmala and Sebastyański 2013). Since the shipyard grounds to be redeveloped are owned by private investors, the municipal council has limited power to influence decisions as to what should be demolished or preserved. However, because of the association of such grounds with Solidarność, the mayor of Gdańsk made it clear that the redevelopment project would rely on consensus and cooperation between the municipal council and civil society. In 2009, the municipal council itself organized several symposia and public meetings to communicate to the public the plans to redevelop the shipyard as the "Young City" (Młode Miasto), a compound settlement originally established by the Teutonic Knights in 1380. This had been home to timber warehouses until the eighteenth century, and in 1844 the Prussian state turned it into a shipyard.

The redevelopment, as it has been planned, will involve the construction of luxury apartments on the waterfront, as well as offices, hotels, a shopping mall, and a big supermarket (Grabkowska 2006: 91-92). The organization of spectacular urban spaces through the creation of an atmosphere of leisure parallels situations recorded in other parts of Poland and Central Europe (Czepczyński 2008; Pozniak 2015; Weszkalnys 2010; Young and Kaczmarek 2008), as well as in contexts where the "authenticity" of historic places becomes available only to those "who have the cultural capital to appreciate the aesthetics of heritage and the financial capital to buy into it" (Zukin 2010: 87; see also Edensor 2005: 72-79; Harvey 1989: 92; High and Lewis 2007: 8-13). Such situations are found in former industrial towns that shift their economies from production to consumption, and promote revitalization projects based on culture and heritage. In the context of this shift, culture (like the "culture of freedom") becomes a substitute for all the lost factories and warehouses (Milner 2007: 189). However, the association between the site and Solidarność gives the project a political "flavor": the brochure issued by the company managing the grounds to be redeveloped clearly states that the initiative is designed to commemorate the achievements of Solidarność. ${ }^{13}$ The Civic Platform-led municipal council highlighted this association particularly on 4 June 2009 and 31 August 2010, respectively the twentieth anniversary of the first "free" elections in Poland and the thirtieth anniversary of the formation of Solidarność, by staging the celebrations of these anniversaries (which I attended) in the shipyard itself.

\section{Whose shipyard?}

One key point of the application materials for the title of European Capital of Culture is that rebuilding solidarity is conditional on the revitalization of areas in a state of decay and on the creation of cultural institutions in the city (Urząd Miejski w Gdańsku 2011: 19). Although in 2011 the municipal council received news that its application had not been successful, it did not give up some of the projects it had already undertaken: the summer of that year saw the beginning of the construction of an imposing building standing by Gate 2, which houses the European Solidarity Center (ECS). A discussion of its goals would require an article in its own right. I will simply say that the ECS is a municipal and state-funded research institution that houses a multimedia exhibition narrating the history of Solidarność. As a research institution, it also documents the activities of opposition movements in late socialism and promotes educational programs for young people (see ECS 2018).

In the past, the Solidarność trade union had actively supported the creation of the ECS. However, although both entities cast Solidarność as a movement that fought for freedom and democracy, they attach different meanings to it: for the former, Solidarność was and remains a trade union whose mission is the protection of workers' rights (for details about the trade union's goals, see Solidarność 2018); for the latter, Solidarność 
was instead a social movement that fought for human rights and contributed to the unification of Europe. While for the trade union's current president, "There is only one Solidarity" (Jest jedna Solidarność), the exhibition housed in the ECS narrates the history of Solidarność from its formation until the demise of the socialist state, but says nothing about the trade union's activities after 1989. Such visions largely reflect the divisions in the Polish memory field: while the trade union largely shares Law and Justice's view that the 1989 negotiations between Solidarność and the socialist state were a betrayal, the ECS propagates instead Civic Platform's view that such negotiations marked the birth of a free and democratic Poland (Bernhard and Kubik 2014: 61-67).

Ever since the construction of the ECS started, media coverage of the redevelopment of the shipyard has been quite extensive. Both national and local newspapers published several articles illustrating the plans to redevelop the shipyard (see Daszczyński 2015; Karaś et al. 2013; Karendys 2016b; Knera 2014; Włodkowska 2009). Yet, there was also widespread awareness that media coverage had to be taken with a grain of salt. As an architectural historian told me, "Nobody knows what the shipyard will look like in the future." These projects stirred up anger when the mayor of Gdańsk contemplated the idea of turning some landmarks associated with Solidarność into heritage sites, one of which is Gate 2. In 1967, the shipyard was named after Lenin, and until 1990 it bore a dedication to the socialist leader over Gate 2 (Stocznia Gdańska im. Lenina). When the Lenin dedication was removed, the gate became adorned with national and religious symbols such as the Polish flag and images of the late Pope John Paul II and of the Black Madonna of Częstochowa. Later on, when the shipyard was downsized, the gate became municipal property. In May 2012, the mayor, with the backing of municipal and regional conservators, reinstated the dedication. Behind this initiative was the idea that restoring the original Cold War appearance of the gate would help turn the area into a protected her- itage site and make young people aware of the shipyard's history. However, when I visited the site, in the summer of 2012, I found that the gate bore little resemblance to the one that I had seen the year before: most of the built structure supporting the dedication had been demolished, and of the "original" gate there remained only the receptionist lodge and the Gdańsk Shipyard (Stocznia Gdańska) sign. In other words, the gate was not so much the product of restoration as it was of demolition.

Despite the mayor's efforts to endow his plan with an aura of legitimacy, the initiative stirred up nationalist feelings among supporters of Law and Justice and members of the Solidarność trade union, who staged protests in front of the gate (see Wybierz Polskę 2012). To make things worse, the mayor's plan was announced at the same time as it turned out that the redevelopment of the shipyard had not yet attracted the hoped-for investments. Because such investments were conditional on the existence of a road linking the shipyard site to the main thoroughfares, its construction ended up draining the public funds that had formerly been allocated to social programs. As a result, the Solidarność trade union proposed a referendum to recall the mayor. In the face of such opposition, the mayor decided to remove the dedication, and the referendum was not held. Yet he did not stop the works that he had already approved, and in the spring of 2013 the shipyard saw the beginning of the long-awaited road construction.

Such works generated much anxiety among the families living in the late nineteenth-century apartment blocks next to the shipyard. I happened to be in the shipyard when works started, and heard local residents criticizing the mayor. One of these associated him with the "developers' mafia" (mafia deweloperska), a term reminiscent of the language of the anticommunist resistance that is now deployed when unaccountability and corruption become topics of moral commentary (Hann 2002: 11; Kalb 2009: 210; Porter-Szücs 2014: 355). Another man living in the same neighborhood expressed con- 
sternation about the news that a substantial part of the shipyard, the birthplace of Solidarność, would be pulled down. Yet his consternation also derived from the fact that even though the company managing the grounds to be redeveloped had a clear commitment to "respect" Polish history, as stated in its brochure, it was not yet clear which landmarks would be saved from demolition. Gate 2, the nineteenth-century administration building, the hall where the 1980 Gdańsk agreements were signed, and a few cranes were already on a list of protected landmarks, but the fate of other buildings was still uncertain.

The fast pace of demolition of warehouses and cranes generated acute awareness among local cultural institutions, intellectuals, artists, architects, and university students of the value of industrial heritage. This awareness subsequently led to the formation of a social initiative (społeczna inicjatywa) called NO to the Demolition of the Gdańsk Shipyard (NIE dla burzenia Stoczni Gdańskiej). Thus, when the construction of the road and of the ECS was in progress, the residents of Gdańsk were confronted with three visions of the shipyard: that of the company managing the grounds (and of the municipal council, to a certain extent), for which such grounds are defined by their economic value; that of the Solidarność trade union, which casts the shipyard as a monument to national history; and that of the social initiative against the demolition of the shipyard, which defines it as industrial heritage.

Despite their different visions, the social initiative and the company managing the grounds did engage in some form of cooperation. In the summer of 2014, they undertook a joint project called Open Garden (Otwarty Ogród), which promoted backyard gardening and collective action among the families residing next to the shipyard. While the aim of the project was to encourage the local community to join forces and sow and plant herbs and vegetables in handmade boxes, its coordinators also organized several walking tours around the shipyard to engage residents in discussions about its legacies. Whereas this initiative has the potential to pro- mote an image of the shipyard as a desirable place to live, it may also promote the sense of solidarity that figures centrally in the materials that the municipal council had previously submitted for the status of European Capital of Culture. However, it is also consistent with a hegemonic neoliberal discourse extolling the virtues of civil society and calling for its empowerment through various forms of engagement to solve its own problems with little or no cost to the downsized postsocialist state.

I joined one of the sessions of the Open Garden project a few weeks after it had been launched. This session was meant to give local residents a chance to get together on a Sunday and share the vegetarian food that they had cooked themselves. I arrived when the session was already in progress only to find out that the people who had turned up were the organizers and a few close friends. When the session came to an end, I asked the university students in charge of the event about the extent of residents' participation in such initiatives. One of these, a graduate student in urban planning, replied that even though several people had participated when the project had been launched, keeping their interest alive turned out to be more challenging than anticipated. One problem, she added, was their very limited interest in buildings dating back to the time when the city was under German rule, namely, buildings that are not deemed part of Polish history. The other problem was that most of those who used to work in the shipyard and subsequently lost their jobs are not eager to see their former workplace falling into pieces. In this sense, the shipyard remains a condensation of the political and moral concerns surrounding Poland's adoption of a free market economy.

Despite the extensive media coverage of the construction of the new ECS building, its opening, which was expected to take place in June 2014, had to be postponed by three months. Moreover, the construction of the road linking the shipyard to the main thoroughfares resulted in the demolition of several late nineteenthcentury buildings. Thus, by the time these works 
came to an end, most of the shipyard site was reduced to a pile of rubble, and the grounds surrounding the ECS were empty. The project became an object of considerable debate when the residents of Gdańsk woke up to the news that the new road had been built very close to the historic housing blocks next to the shipyard, and that its construction was the execution of a plan conceived in the socialist era. Paradoxically, although the ECS is meant to remind the residents of Gdańsk and Poles more generally that the shipyard is the place where the new (i.e., postsocialist) Poland was born, nothing is left around the new building (with the exception of Gate 2) of the built environment within which Solidarność was formed. In this sense, the construction of the ECS building and of the road operated through the expansive logic of abstract space (Gordillo 2014: 82) and ended up disembedding Solidarność from most of the site.

\section{Conclusion}

When I revisited Gdańsk in the summer of 2016, the ECS was up and running, yet the grounds surrounding it were still waiting to be redeveloped. Most visions and plans, then, have so far failed to translate into built realities: when the redevelopment project was conceived, it was largely driven by the optimism deriving from the flow of global capital into Poland after its EU accession. However, the unexpected demolition of some nineteenth-century warehouses in late 2014 prompted the social initiative NO to the Demolition of the Gdańsk Shipyard and the ECS director to join forces and petition then President Bronisław Komorowski to prevent the shipyard from undergoing further destruction. Behind their petition was the idea that, because the shipyard is industrial heritage and part of the identity of the city, it needs to be preserved. Komorowski, in turn, wrote a note to the mayor of Gdańsk to advise him that the protection of the shipyard grounds was a moral duty (Sandecki 2014). The mayor, in response, commissioned the compilation of a list of buildings to be saved from demolition (Sandecki 2015). Although the buildings whose demolition had already been approved could not be saved on the grounds that they were in a state of disrepair and of no economic value (Karendys 2016a), many of those built in the nineteenth century were included in the above list (Stawikowska 2016). Meanwhile, the company managing the grounds commissioned a group of international architects to develop an architectural concept of the area next to the ECS (Karendys 2016c). Yet their computer rendering images functioned primarily as "representational forms" meant to shape expectations (Holmes 2014: 23). Although "nobody knows what the shipyard will look like in the future," as the aforementioned architectural historian stated, such images enabled the company to enter into contractual agreements with construction companies.

The discussion of the reorganization of public memory space brings us back to the question asked at the outset, namely, what legitimated the municipal councils' authority over its memorial landscapes. As we have seen, the continued emphasis on a state-sanctioned notion of local identity suggests that there is hardly a conceptual opposition between "national" and "local" narratives of the recent past. ${ }^{14}$ The fact that a redefinition of the local past from below is not on the agenda of the ECS is a case in point. However, the effect of memory places, such as the shipyard grounds that were to be redeveloped, may be quite ambiguous: as Paul Connerton (2009: 27) has suggested, "the desire to memorialize is precipitated by a fear, a threat, of cultural amnesia." On the one hand, this fear derives from the fact that different histories (Prussian, German, socialist, industrial, Polish, European) intersect in the shipyard: therefore, throwing into relief one "history" may have the effect of downplaying another; on the other hand, the redevelopment, no matter what form it will take, will not reconstruct the past but will obliterate part of it. In this sense, the redevelopment of the shipyard grounds is as much about construction as it is about destruction. What mobilized political action in Gdańsk was not so much construction as 
demolition and, more particularly, opposition to Civic Platform's "building politics."

Reconstructions and redevelopments are not new in Polish history: in a country that had been the theater of conflict, they often served to revitalize communities after a period of crisis, yet they also set out to rewrite (or revisit) local and national history. Gdańsk's reinvention as a Polish city in the aftermath of World War II and the development of industrial areas were founded on the erasure of the recent past and were intended to inscribe, inter alia, a socialist vision of society onto the urban landscape. To some extent, the planned redevelopment of the shipyard site forms part of the same story, since both the municipal council and developers sought to assert (at least nominally) the erasure of socialism from the postindustrial areas they wanted to see redeveloped.

Paradoxically, while the municipal council and the Polish state set out to commemorate a social movement that paved the way for the birth of the new Poland, the material traces of the past to be commemorated were turned into piles of rubble or wasteland (Gordillo 2014: 206), and what has just been built (i.e., the road) had been planned in the socialist era. Yet, preventing the shipyard grounds from being redeveloped would be at odds with the workings of the free market economy. Although municipal councils are in charge of shaping historical memory and of reorganizing public memory space, they have to negotiate between the need for legitimacy, which is conditional on championing moral and social values such as "freedom" and "solidarity," and the workings of the market to which they are bound. In this sense, both demolition and the identification of "ruins" lacking economic value are political acts (Schwenkel 2013: 257; Stoler 2008: 196). Because the redevelopment project, like other projects, aimed to produce a systematic stabilization from an unstable material world (Harvey and Knox 2015: 122), ruins can be political capital for the politicians who promise to reorder not just the shipyard's material world but also Gdańsk's complicated history, especially at a time when everything (including Poland's political situation) is fluid and uncertain.
There are grounds for arguing, then, that what legitimated municipal councils' authority over their memorial landscapes was not so much their rediscovery of a multicultural heritage as their ability to define the local past largely in "material" terms, namely, as something that needs to be reordered both materially and symbolically. The contradictions with which the redevelopment project is rife are suggestive for what they tell us about the management of narratives in times of economic crisis. If the empirical task is to make sense of such contradictions, it also points to an analytical challenge, which is to think about the reorganization of public memory spaces as a fluid process that is bound up with the production and circulation of information, which may be vital to "building" memorial landscapes as empirical facts.

\section{Acknowledgments}

Most of the field research conducted in Poland, on which this work is based, was made possible by three research grants awarded from the Faculty Research, Scholarly Activity and Creative Achievement Fund of Grant MacEwan University (now MacEwan University). I am grateful to Michał Buchowski, Marysia Galbraith, Douglas Holmes, Frances Pine, and two anonymous reviewers for their constructive criticism on earlier versions of this article, which have helped to stir my thoughts and refine my argument.

Jaro Stacul is Visiting Assistant Professor of Anthropology at Memorial University of Newfoundland in Corner Brook, Canada. He has worked in various academic institutions in Britain and Canada and is the author of The Bounded Field: Localism and Local Identity in an Italian Alpine Valley (2003) and coeditor (with Christina Moutsou and Helen Kopnina) of Crossing European Boundaries: Beyond Conventional Geographical Categories (2005), both of which were published by Berghahn Books. E-mail: jstacul@mun.ca 


\section{Notes}

1. Although Solidarność was built by workers in 1980, its politics followed fully from the narratives spun by its democratic intellectual opponents of the 1970s (Ost 2005: 191; Tighe 1990: 243-244).

2. I draw here from fieldwork conducted in the Gdańsk area from 2008 onward. I base my discussion on informal conversations, attendance at official events, observations of the practices of residents involved in a wide range of cultural activities, and the examination of published and unpublished materials. I have also visited several historical exhibitions and have observed different projects as they unfold and people's reactions to them.

3. In the 2011 electoral campaign, Civic Platform made use of both "We are building Poland" and "Poland under construction" (Polska w budowie) in brochures and video clips illustrating what the party had accomplished and what it was planning to achieve. The football championships were known as UEFA Euro 2012 (Union of European Football Associations).

4. In a situation of economic uncertainty, historical analogies are used by a wide range of political actors to get people to understand present circumstances by looking for precedents in another era (Humphrey 2009: 231). I am indebted to Lesław Michałowski for letting me know about the historical analogy used by the mayor.

5. I am grateful to Agata Bachórz for drawing my attention to the significance of "building" in local discourses.

6. Eventually, the status was awarded to the Polish city of Wrocław.

7. Created in 1998, the IPN's mission is to manage and disclose the materials of the state security agencies dated to between 1944 and 1989.

8. Solidarność came into being through a dialogue between workers and intellectuals. However, it "was a multi-stranded and complicated social entity from the beginning of its existence" (Kubik 1994: 232).

9. "Freedom" thus conceived consists in the freedom to foster the common good, and entails many possibilities not included in simply pursuing one's own freedom (Beyer 2010: 14-21).

10. This was an implicit reference to political divisions in Polish society. It is not purely coinci- dence that in his successful 2010 presidential campaign Bronisław Komorowski deployed the slogan "Unity builds" (Zgoda buduje).

11. Memory (or the lack thereof) plays a significant role in conjuring up this image, given that very few people living in the city have firsthand memories of the time when Gdańsk was German (Mendel 2010).

12. It is important to make a distinction between Solidarność as a trade union and Solidarność as a political party: as a trade union, it continues to represent the workers, although not in the way it did in late socialism.

13. The brochure (in Polish and English) was entitled "Young City: Freedom Sets Sail." It does not have a printing date. However, it makes explicit reference to the plans announced in 2006, and states that the construction of a road linking the shipyard to the main thoroughfares was agreed upon in 2008. I got hold of it in the summer of 2009.

14. Gdańsk's prominent place in national historiography also stems from the fact that quite a few leading politicians (e.g., Lech Wałęsa and former Prime Minister Donald Tusk) are natives of Gdańsk itself or have lived in the area.

\section{References}

Adamowicz, Paweł. 2008. Gdańsk jako wyzwanie [Gdańsk as a challenge]. Gdańsk: Słowo/Obraz Terytoria.

Bauman, Zygmunt. 1988. Freedom. Milton Keynes: Open University Press.

Bernhard, Michael, and Jan Kubik. 2014. "Roundtable discord: The contested legacy of 1989 in Poland." In Twenty years after communism: The politics of memory and commemoration, ed. Michael Bernhard and Jan Kubik, 60-84. Oxford: Oxford University Press.

Beyer, Gerald. 2010. Recovering solidarity: Lessons from Poland's unfinished revolution. Notre Dame, IN: University of Notre Dame Press.

Connerton, Paul. 2009. How modernity forgets. Cambridge: Cambridge University Press. Czepczyński, Mariusz. 2004. "Living the cultural landscape: The heritage and identity of the inhabitants of Gdańsk." In Featuring the quality of urban life in contemporary cities of Eastern and Western Europe, ed. Iwona Sagan and Mariusz 
Czepczyński, 275-288. Poznań: Bogucki Wydawnictwo Naukowe.

Czepczyński, Mariusz. 2008. Cultural landscapes of post-socialist cities: Representation of powers and needs. Aldershot: Ashgate.

Daszczyński, Roman. 2015. "Viva Solidarity." Gazeta Wyborcza Trójmiasto, 24 April (special issue in English).

Davies, Norman. 2001. Heart of Europe: The past in Poland's present. Oxford: Oxford University Press.

Dunn, Elizabeth. 2004. Privatizing Poland: Baby food, big business, and the remaking of labor. Ithaca, NY: Cornell University Press.

ECS (European Solidarity Center). 2018. "The mission: Discover history and decide about the future." Accessed 29 March. http://www.ecs.gda .pl/title,Jezyk,pid,29,lang,2.html.

Edensor, Tim. 2005. Industrial ruins: Space, aesthetics and materiality. Oxford: Berg.

Friedrich, Jacek. 2012. "Polish and German heritage in Danzig/Gdańsk: 1918, 1945 and 1989.” In Heritage, ideology and identity in Central and Eastern Europe: Contested pasts, contested presents, ed. Matthew Rampley, 115-129. Woodbridge: Boydell.

Galbraith, Marysia. 2014. Being and becoming European in Poland: European integration and self-identity. London: Anthem.

Gordillo, Gastón. 2014. Rubble: The afterlife of destruction. Durham, NC: Duke University Press.

Grabkowska, Maja. 2006. "Przemiany krajobrazu postindustrialnego na przykładzie gdańskich terenów postoczniowych" [Transformations of the postindustrial landscape on the example of the Gdańsk post-shipyard areas]. In Przestrzenie miast postsocjalistycznych: Studia społecznych przemian przestrzeni zurbanizowanej [The spaces of postsocialist cities: Studies of social changes of urban space], ed. Mariusz Czepczyński, 85-97. Poznań: Bogucki Wydawnictwo Naukowe.

Grzeszak, Adam, and Mariusz Janicki. 2011. "Wojny miast" [Wars of cities]. Polityka 27 (2814): 16-18.

Hann, Chris. 2002. "Farewell to the socialist 'other." In Postsocialism: Ideals, ideologies and practices in Eurasia, ed. Chris Hann, 1-11. London: Routledge.

Hardy, Jane. 2009. Poland's new capitalism. London: Pluto Press.

Harvey, David. 1989. The condition of postmodernity: An enquiry into the origins of cultural change. Oxford: Blackwell.
Harvey, Penny, and Hannah Knox. 2015. Roads: An anthropology of infrastructure and expertise. Ithaca, NY: Cornell University Press.

High, Steven, and David Lewis. 2007. Corporate wasteland: The landscape and memory of deindustrialization. Ithaca, NY: Cornell University Press.

Holmes, Douglas. 2014. Economy of words: Communicative imperatives in central banks. Chicago: University of Chicago Press.

Humphrey, Caroline. 2009. "Historical analogies and the commune: The case of Putin/Stolypin." In Enduring socialism: Explorations of revolution and transformation, restoration and continuation, ed. Harry West and Parvathi Raman, 231-249. Oxford: Berghahn Books.

Jarecki, Edward. 1985. Stocznia Gdańska im. Lenina: Życie społeczno-polityczne w latach 1945-1984 [Gdańsk Shipyard Lenin: Social and political life in the years 1945-1984]. Warsaw: Książka i Wiedza.

Kalb, Don. 2009. "Conversation with a Polish populist: Tracing hidden histories of globalization, class, and dispossession in postsocialism (and beyond)." American Ethnologist 36 (2): 207-223.

Karaś, Dorota, Michał Jamroż, and Krzysztof Katka. 2013. "Życie w stolicy Europy" [Life in the capital of Europe]. Gazeta Wyborcza, 11 January.

Karendys, Ewa. 2016a. "Znika kolejna stoczniowa hala" [The next shipyard hall disappears]. Gazeta Wyborcza Trójmiasto, 20-21 February.

Karendys, Ewa. 2016b. "Wartością architektury jest to, co daje miastu" [The value of architecture is what it gives the city]. Gazeta Wyborcza Trójmiasto, 4 March.

Karendys, Ewa. 2016c. "Jakie będzie Młode Miasto?" [What will the Young City be like?] Gazeta Wyborcza Trójmiasto, 15 April.

Kideckel, David. 2008. Getting by in postsocialist Romania: Labor, the body, and working-class culture. Bloomington: Indiana University Press.

Knera, Jakub. 2014. "Albo muzeum, albo ruch" [Either a museum or movement]. Polityka 35 (2973): 92-94.

Kosmala, Katarzyna, and Roman Sebastyański. 2013. "The roles of artists' collective in the Gdańsk Shipyard's heritage protection.” Journal of Cultural Heritage and Sustainable Development 3 (2): 116-129.

Kubik, Jan. 1994. The power of symbols against the symbols of power: The rise of solidarity and the 
fall of state socialism in Poland. University Park: Pennsylvania State University Press.

Laszczkowski, Mateusz. 2011. "Building the future: Construction, temporality, and politics in Astana." Focaal 60: 77-92.

Latoszek, Marek. 2003. "Dziedzictwo 'Solidarności': Dar dla tożsamości gdańszczan" [Heritages of "solidarity": A gift for the identity of the inhabitants of Gdańsk]. In Tożsamośc miejsca i ludzi: Gdańszanie i ich miasto w perspektywie historyczno-socjologicznej [The identity of the place and its people: The inhabitants of Gdańsk and their city from a historical and sociological perspective], ed. Małgorzata Dymnicka and Zbigniew Opacki, 182-192. Warsaw: Oficyna Naukowa.

Lukowski, Jerzy, and Herbert Zawadzki. 2006. A concise history of Poland. Cambridge: Cambridge University Press.

Mach, Zdzisław. 2007. "Constructing identities in a post-communist society: Ethnic, national, and European." In Identity and networks: Fashioning gender and ethnicity across cultures, ed. Deborah F. Bryceson, Judith Okely, and Jonathan Webber, 54-72. Oxford: Berghahn Books.

Mark, James. 2010. The unfinished revolution: Making sense of the communist past in Central-Eastern Europe. New Haven, CT: Yale University Press.

Mendel, Maria. 2010. “Tożsamość zbiorowa jako lokalność" [Collective identity as a locality]. In Tożsamość gdańszczan: Budowanie na (nie) pamięci [Identity of the citizens of Gdańsk: Building on (not) memory], ed. Maria Mendel and Alicja Zbierzchowska, 371-395. Gdańsk: Wydawnictwo Uniwersytetu Gdańskiego.

Michałowski, Lesław. 2010. "Trójmiasto: Jedna przestrzeń, trzy mity” [Tricity: One space, three myths]. In Pamięć, przestrzeń, tożsamość [Memory, space, identity], ed. Sławomir Kapralski, 257-278. Warsaw: Wydawnictwo Naukowe Scholar.

Milner, Susan. 2007. "Cultural identities and the European city." In The European puzzle: The political structuring of cultural identities at a time of transition, ed. Marion Demossier, 183-206. Oxford: Berghahn Books.

Murawski, Michał. 2011. "Inappropriate object: Warsaw and the Stalin-era Palace of Culture after the Smolensk disaster." Anthropology Today 27 (4): 5-10.

Ochman, Ewa. 2009. "Municipalities and the search for the local past: Fragmented memory of the
Red Army in Upper Silesia." East European Politics and Societies 23 (3): 392-420.

Orla-Bukowska, Annamaria. 2006. "New threads on an old loom: National memory and social identity in postwar and post-communist Poland." In The politics of memory in postwar Europe, ed. Richard Lebow, Wulf Kansteiner, and Claudio Fogu, 177-209. Durham, NC: Duke University Press.

Ost, David. 2005. The defeat of solidarity: Anger and politics in postcommunist Europe. Ithaca, NY: Cornell University Press.

Parkin, Robert. 2013. "Regionalisation in Eastern Europe: The case of Lubuskie, Poland." Anthropological Journal of European Cultures 22 (1): 115-137.

Porter-Szűcs, Brian. 2014. Poland in the modern world: Beyond martyrdom. Hoboken, NJ:

Wiley-Blackwell.

Pozniak, Kinga. 2015. "A model socialist steel town enters the neoliberal age: The changing political economy of Nowa Huta, Poland." Economic Anthropology 2 (1): 63-83.

Richardson, Tanya. 2008. Kaleidoscopic Odessa: History and place in contemporary Ukraine. Toronto: University of Toronto Press.

Sandecki, Maciej. 2014. "Prezydent broni stoczni" [The president defends the shipyard]. Gazeta Wyborcza Trójmiasto, 24-26 December.

Sandecki, Maciej. 2015. "Przełom w sprawie stoczni" [A breakthrough in the shipyard's case]. Gazeta Wyborcza Trójmiasto, 21 January.

Schwenkel, Christina. 2013. "Post/socialist affect: Ruination and reconstruction of the nation in urban Vietnam." Cultural Anthropology 28 (2): 252-277.

Shields, Stuart. 2007. "From socialist solidarity to neo-populist neoliberalisation? The paradoxes of Poland's post-communist transition." Capital and Class 31 (3): 159-178.

Solidarność. 2018. “Objectives." Accessed 29 March. http://www.solidarnosc.org.pl/en/about/ objectives.

Stawikowska, Emilia. 2016. "Stocznia Cesarska do rejestru" [Imperial shipyard to the registry] Gazeta Wyborcza Trójmiasto, 11 March.

Stoler, Ann. 2008. "Imperial debris: Reflections on ruins and ruination." Cultural Anthropology 23 (2): 191-219.

Tighe, Carl. 1990. Gdańsk: National identity in the Polish-German borderlands. London: Pluto Press. 
Urząd Miejski w Gdańsku. 2011. Formularz kandydatury Gdańska do tytułu Europejskiej Stolicy Kultury 2016 [Gdańsk's application form for the title of the European Capital of Culture 2016]. Gdańsk: Urząd Miejski.

Verdery, Katherine. 1999. The political lives of dead bodies: Reburial and postsocialist change. New York: Columbia University Press.

Weszkalnys, Gisa. 2010. Berlin, Alexanderplatz: Transforming place in a unified Germany. Oxford: Berghahn Books.

Włodkowska, Katarzyna. 2009. "ECS to priorytet" [ECS is a priority]. Gazeta Wyborcza Trójmiasto, 12 June.

Wojciechowski, Henryk. 1966. Stocznia Gdańska w dwudziestoleciu 1945-1965 [Gdańsk Shipyard in the twenty-year period 1945-1965]. Gdańsk: Stocznia Gdańska.
Wybierz Polskę. 2012. "Stocznia Gdańska ponownie im. Lenina" [Gdańsk Lenin Shipyard again]. Video, 6:56. 15 May. https://www.youtube.com/ watch? $\mathrm{v}=\mathrm{mDZtDoH} 50 \mathrm{kc}$.

Young, Craig, and Sylvia Kaczmarek. 2008. “The socialist past and postsocialist urban identity in Central and Eastern Europe: The case of Łódź, Poland." European Urban and Regional Studies 15 (1): 53-70.

Zubrzycki, Geneviève. 2006. The crosses of Auschwitz: Nationalism and religion in post-communist Poland. Chicago: University of Chicago Press.

Zubrzycki, Geneviève. 2011. "History and the national sensorium: Making sense of Polish mythology." Qualitative Sociology 34 (1): 21-57.

Zukin, Sharon. 2010. Naked city: The death and life of authentic urban places. Oxford: Oxford University Press. 